\author{
ANNA LAMTYCH \\ Uniwersytet Mikołaja Kopernika w Toruniu \\ annalamtych@op.pl
}

\title{
Wynagrodzenie skazanych za pracę wykonywaną w okresie odbywania kary pozbawienia wolności
}

\author{
Remuneration of sentencedpersons for workper for medduringtheirterms of \\ imprisonment
}

Streszczenie: Praca osób skazanych stanowi zjawisko niezwykle istotne, posiadające ogromny wpływ na cały proces resocjalizacji. Świadczenie pracy przez skazanych determinuje powstanie stosunku prawnego, który różni się od klasycznego stosunku pracy. Bez względu jednak na podstawę wykonywanej pracy, jednym $\mathrm{z}$ istotnych aspektów jest wynagrodzenie. Celem niniejszego opracowania będzie przedstawienie problematyki wynagrodzenia osób skazanych za pracę wykonywaną w okresie odbywania kary pozbawienia wolności. W artykule zawarte zostaną rozważania dotyczące wysokość wynagrodzenia poczynione na tle obowiązujących regulacji prawnych, jak i stanu prawnego obowiązującego od roku 2003 do 2011, zasady dokonywania potrąceń i przekazywania wynagrodzenia oraz zagadnienie przestoju, jako przeszkody w świadczeniu pracy.

Słowa kluczowe: praca; osoby skazane; wynagrodzenie; potrącenia z wynagrodzenia; prawo pracy; prawo karne wykonawcze.

Summary: The work of prisonersisan extremely important phenomenon, which has a hugeimpact on the wholeprocess of resocialization. The provision of work by convictsdetermines the establishment of a legalrelationshipwhichdiffers from the classic employmentrelationship. However, regardless of the basis of the work, one essentialaspectisremuneration. The purpose of thisstudywill be to present the issue of remuneration of convictedpersons for workperformedduringimprisonment. The articlewillincludeconsiderationsregarding the amount of remuneration, madeagainst the background of applicablelegalregulations as well as the legal status in force from 2003 to 2011, rules for makingdeductions and remuneration, as well as the issue of downtime as anobstacle to work.

Keywords: job; sentencedpersons, remuneration, deductions with remuneration; labour law; executivecriminal law; deductions with remuneration. 


\section{Wstęp}

Podejmowanie pracy przez osoby pozbawione wolności jest zjawiskiem pożądanym pod wieloma aspektami, do których zalicza się między innymi aspekt resocjalizacyjny oraz ekonomiczny. Wobec silnego rozwoju znaczenia funkcji i zadań wychowawczych kary, w tym kary pozbawienia wolności, zatrudnienie w jej warunkach wywiera mniejszą rolę ekonomiczną, pokładając swój główny nacisk na aspekt resocjalizacyjny ${ }^{1}$. Praca osób pozbawionych wolności stanowi ważny element w ich życiu, co zostało wyraźnie zaakcentowane przez ustawodawcę w art. 1 ust. 2 ustawy o zatrudnianiu osób pozbawionych wolności ${ }^{2}$, jak i w orzecznictwie, gdzie wyraźnie podkreśla się, iż celem pracy jest przede wszystkim pozytywne oddziaływanie na postawy skazanych ${ }^{3}$.Taki stan rzeczy niewątpliwie wyłania na pierwsze miejsce niemajątkowe wartości pracy, jednakże nie można w tym miejscu zapominać o aspekcie majątkowym, jakim jest wynagrodzenie za pracę. Dzięki wykonywaniu odpłatnej pracy osobie skazanej daje się realną szansę na wywiązywanie się przez nią z ciążących na niej obowiązków, głównie obowiązków majątkowych. Skazany otrzymuje możliwość gromadzenia środków pieniężnych, które zapewnią mu szybki powrót do właściwego funkcjonowania po opuszczeniu zakładu karnego, jaki i również, jest szansą na wspomaganie finansowe rodziny, co odgrywa ważny czynnik przy utrzymywania i pogłębianiu relacji z osobami najbliższymi, które stanowią istotne wsparcie dla całego procesu resocjalizacji ${ }^{4}$.

Celem niniejszego opracowania jest analiza zasad przyznawania wynagrodzenia przysługującego osobom pozbawionych wolności za wykonywaną przez nich pracę, a więc wyłącznie jednego zagadnienia, które ściśle związane jest ze świadczeniem pracy przez osoby pozbawione wolności. Celem autora będzie przedstawienie regulacji dotyczącej wysokości wynagrodzenia minimalnego, zasad dokonywania potrąceń i przekazywania wynagrodzenia oraz zagadnienie wpływu przestoju w świadczeniu pracy na wynagrodzenie. Ukazanie regulacji prawnych dotyczących płacy za pracę osób pozbawionych wolności opierać będzie się na przybliżeniu i ocenie obecnego stanu prawnego, jak i również zestawieniu go ze stanem prawnym obowiązującym w latach 2003-2011 w zakresie, w jakim odnosił się on do wysokości minimalnego wynagrodzenia.

\footnotetext{
${ }^{1}$ E. Dawidziuk, Traktowanie osób pozbawionych wolności we współczesnej Polsce na tle standardów międzynarodowych, Warszawa 2013,s. 158.

${ }^{2}$ Ustawa z dnia 28 sierpnia 1997 r. o zatrudnianiu osób pozbawionych wolności (tekst jedn.: Dz.U. z 2017 r. poz. 2151).

${ }^{3}$ Wyrok Trybunału Konstytucyjnego z dnia 13 grudnia 2004 r., K 20/04, Dz.U. Nr 273, poz. 2720.

${ }^{4}$ M. Kuć, Prawne podstawy resocjalizacji, Warszawa 2011, s. 92.
} 


\section{Wysokość wynagrodzenia za pracę osób skazanych}

\subsection{Analiza obowiązującej regulacji prawnej}

W obecnym stanie prawnym zasadą jest, iż nieodłącznym elementem świadczenia pracy przez osoby pozbawione wolności jest wynagrodzenie za pracę. Kodeks karny wykonawczy ${ }^{5}$ $\mathrm{w}$ art. $123 \S 1$ in principio wyraźnie wskazuje, iż praca skazanego jest odpłatna. Ściśle koresponduje to z poglądem, iż niedopuszczalne jest zatrudnianie osób skazanych w ramach ich głównego zajęcia, będącego realizacją ustawowego prawa i obowiązku pracy, bez stosownej odpłatności ${ }^{6}$. Tak sformułowana zasada stanowi wyznacznik godziwego wynagrodzenia oraz równego traktowania $\mathrm{w}$ zatrudnieniu, co zostało potwierdzone i zagwarantowane przez standardy prawa międzynarodowego, które rozciągają swoją moc wiążącą na uregulowania wewnątrzkrajowe. Najistotniejszym jednak elementem wynagrodzenia jest jego wysokość. Na tle standardów europejskich wskazuje się, iż wysokość godziwego czy też sprawiedliwego wynagrodzenia (ang. fair remuneration) to taka wysokość, która zapewni pracownikowi i jego rodzinie godziwy poziom życia ${ }^{7}$. W przełożeniu na uregulowania, jakie możemy znaleźć w polskim systemie prawa, wyznacznikiem tak rozumianej wysokości wynagrodzenia jest wynagrodzenie minimalne, ustalane corocznie w ramach negocjacji Rady Dialogu Społecznego ${ }^{8}$. Przepisom odnoszącym się do minimalnego poziomu wynagrodzenia przypisywana jest funkcja gwarancyjna, stanowiąca ochronę osób pracujących. Należy w tym miejscu zaznaczyć wagę wskazanego uregulowania przez pryzmat jego uwzględnienia $\mathrm{w}$ ustawie zasadniczej, gdzie z art. 65 Konstytucji Rzeczypospolitej Polski ${ }^{9}$ może być wywodzone prawo podmiotowe do otrzymywania minimalnego wynagrodzenia nie tylko przez pracownika $\mathrm{w}$ rozumieniu art. 2 Kodeksu pracy ${ }^{10}$, ale również, jak wskazuje orzecznictwo przez osobę pozbawioną wolności świadczącą pracę ${ }^{11}$.

Artykuł $123 \S 1$ zdanie drugie Kodeksu karnego wykonawczego wskazuje, iż zasady wynagradzania za pracę osoby skazanej ustala się w porozumieniu zawieranym przez

\footnotetext{
${ }^{5}$ Ustawa z dnia 6 czerwca 1997 r. - Kodeks karny wykonawczy (tekst jedn.: Dz.U. z 2019 r. poz. 676).

${ }^{6} \mathrm{~T}$. Liszcz, Zatrudnienie skazanych odbywajacych karę pozbawienia wolności (podstawowe zagadnienia prawne), „Państwo i Prawo” 1989, z. 2, s. 89-90.

${ }^{7}$ Art. 4 Europejskiej Karty Społecznej z dnia 18 października 1961 r. (Dz.U. z 1999 r. Nr 8, poz. 67).

${ }^{8}$ Art. 2 ustawy z dnia 10 października 2002 r. o minimalnym wynagrodzeniu za pracę (tekst jedn:. Dz.U. z 2018 r. poz. 2177).

${ }^{9}$ Konstytucja Rzeczpospolitej Polski z dnia 2 kwietnia 1997 r. (Dz.U. Nr 78, poz. 483).

${ }^{10}$ Art. 2 ustawy z dnia 26 czerwca 1974 r. - Kodeks pracy z dnia 26 czerwca 1974 r. (tekst jedn. Dz.U. z 2019 r. poz. 1040).

${ }^{11}$ Wyrok Trybunału Konstytucyjnego z dnia 7 stycznia1997 r., K 7/96 OTK 1997, Nr 1, poz. 1.
} 
dyrektora zakładu karnego lub w umowie zawieranej przez skazanego. Z kolei zdanie trzecie przywołanego przepisu odnosi się do sytuacji skierowania skazanego do prac administracyjno-porządkowych na terenie zakładu karnego, w których to przypadkach wynagrodzenie ustalane jest przez dyrektora tego zakładu. Regulacja prawna, która wprost odnosi się do minimalnego poziomu wynagrodzenia osób pozbawionych wolność, zawarta została w art. $123 \S 2$ Kodeksu karnego wykonawczego. Przepis ten w obecnym brzemieniu w zakresie, w jakim odnosi się on do przepracowania przez osobę skazaną pełnego miesięcznego wymiaru czasu pracy lub wykonania pełnej miesięcznej normy pracy wyraźnie wskazuje, iż wynagrodzenie przysługujące skazanemu zatrudnionemu w pełnym wymiarze czasu pracy ustala się w sposób zapewniający osiągnięcie kwoty co najmniej minimalnego wynagrodzenia za pracę ustalanego na podstawie odrębnych przepisów. W wypadku przepracowania niepełnej miesięcznej normy czasu pracy lub niewykonania pełnej miesięcznej normy pracy wynagrodzenie wypłaca się proporcjonalnie do ilości czasu pracy lub wykonanej normy pracy. W razie zatrudnienia skazanego w niepełnym wymiarze czasu pracy najniższe wynagrodzenie ustala się $\mathrm{w}$ kwocie proporcjonalnej do liczby godzin zatrudnienia, biorąc za podstawę kwotę minimalnego wynagrodzenia za pracę. Wskazany przepis wskazuję expressis verbis zasady przyznawania minimalnej wysokość wynagrodzenia, przy czym podkreślenia wymaga to, iż jego obecne brzmienie zostało wprowadzone do Kodeksu karnego wykonawczego ustawą $\mathrm{z}$ dnia 3 lutego 2011 r. nowelizującą kodeks ${ }^{12}$. To zaś oznacza, że przywołana w powyższym artykule zasada dotycząca minimalnego wynagrodzenia za pracę osób pozbawionych wolności ulegała zmianom. Określenie przez ustawodawcę poziomu najniższego wynagrodzenia, a tym samym ustanowienie pewnego minimum, jakie przysługuje osobie skazanej za wykonywanie pracy, jest w przywołanym przepisie najistotniejsze. Najniższe wynagrodzenia za pracę zostało określone w taki sam sposób, w jak uczynił to ustawodawca na gruncie Kodeksu pracy ${ }^{13}$, gdzie tym samym - w aspekcie wynagrodzenia - zrównano pozycję pracownika, a więc osoby zatrudnionej na jednej z podstaw determinujących powstanie stosunku pracy, $\mathrm{z}$ osobą pozbawioną wolności świadczącą pracę. Taki sposób ukształtowania przepisów, który pozwolił na ujednolicenie wysokości najniższego wynagrodzenia za pracę, stanowi ważny czynnik w realizacji zasady równości w zatrudnieniu. Wskazana regulacja przyczynia się jednocześnie do urzeczywistniania uregulowań międzynarodowych, które nakładają na

\footnotetext{
${ }^{12}$ Ustawa z dnia 3 lutego 2011 r. o zmianie ustawy - Kodeks karny wykonawczy oraz niektórych innych ustaw (Dz.U. Nr 39, poz. 292).

${ }^{13}$ Zob. art. $10 \S 2$ oraz art. 13 ustawy z dnia 26 czerwca 1974 r. - Kodeks pracy (tekst jedn. Dz.U. z 2019 r. poz. 1040).
} 
państwa obowiązek stwarzania warunków, gdzie praca wykonywana przez osobę skazaną powinna $\mathrm{w}$ pełni odpowiadać warunkom pracy wykonywanej przez osoby niepozostające w izolacji ${ }^{14}$.

\subsection{Analiza i ocena wcześniejszej regulacji}

Jak wskazane zostało powyżej, brzemiennie art. $123 \S 2$ Kodeksu karnego wykonawczego ulegało licznym zmianom. Istotne będzie odniesienie się w tym miejscu do budzącej kontrowersje w doktrynie i judykaturze nowelizacji art. 123 § 2 Kodeksu karnego wykonawczego, która weszła w życie z dniem 1 września 2003 r. $^{15}$. Wskazana nowelizacja wprowadzała zasadę, w myśl której wynagrodzenie przysługujące skazanemu zatrudnionemu w pełnym wymiarze czasu pracy ustalane było w sposób zapewniający osiągnięcie co najmniej połowy minimalnego wynagrodzenia określonego na podstawie odrębnych przepisów, przy przepracowaniu pełnego miesięcznego wymiaru czasu pracy lub wykonaniu pełnej miesięcznej normy pracy. Natomiast, odnosząc się do zatrudnienia skazanego w niepełnym wymiarze czasu pracy, najniższe wynagrodzenie ustalane było w kwocie proporcjonalnej do liczby godzin zatrudnienia, biorąc za podstawę połowę minimalnego wynagrodzenia. Tak sformułowane brzmienie przepisu powodowało ustalenie najniższego progu wynagrodzenia skazanych na poziomie połowy minimalnego wynagrodzenia rozumianego na gruncie ustawy o minimalnym wynagrodzeniu za pracę. Konstrukcja ta pod względem wysokości gwarantowanego wynagrodzenia, różnicowała sytuację osób skazanych od osób świadczących pracę w warunkach wolnościowych. Znaczące zmniejszenie o połowę - progu najniższej płacy zagwarantowanej przez ustawodawcę każdej osobie, która w warunkach izolacji więziennej podejmie się świadczenia pracy, stanowiło rozwiązanie, które w znaczny sposób niosło za sobą zachwianie zasady równości. Rozwiązanie to rodziło między innymi „obawy co do powrotu do minionych, niechlubnych czasów wyzyskiwania więźniów, gdy z racji ich dyspozycyjności oraz bardzo niskiego wynagrodzenia uzasadnione było określanie ich pracy jako niewolniczej”16. Stąd też niebagatelną rolę odegrał wyrok Trybunału Konstytucyjnego z dnia 23 lutego 2003 r. ${ }^{17}$, który zanegował dotychczasowe rozwiązanie ustawodawcy.

\footnotetext{
${ }^{14}$ Zob. art. 7 Międzynarodowego Paktu Praw Gospodarczych, Socjalnych i Kulturalnych otwarty do podpisu w Nowym Jorku z dnia 19 grudnia 1966 r. (Dz.U. z 1977 r. nr 38, poz. 169).

${ }^{15}$ Ustawa z dnia 24 lipca 2003 r. o zmianie ustawy - Kodeks karny wykonawczy oraz niektórych innych (Dz.U. Nr 142, poz. 1380).

${ }^{16}$ A. Kosut, Zatrudnienie skazanych $w$ świetle projektu zmian kodeksu karnego wykonawczego z 2001 r., „Przegląd Więziennictwa Polskiego” 2001, nr 32-33, s. 68.

${ }^{17}$ Wyrok Trybunały Konstytucyjnego z dnia 23 lutego 2010 r., P 20/09 Dz.U. Nr. 34, poz. 191.
} 
Trybunał Konstytucyjny wyraźnie stwierdził w nim niekonstytucyjność art. $123 \S 2$ Kodeksu karnego wykonawczego w zakresie, w jakim zawiera on słowo „połowy” wynagrodzenia. Wskazany zakres przywołanego przepisu został uznany za niezgodny $\mathrm{z}$ art. 32 Konstytucji, który odnosi się do zasady równości oraz niezgodny art. 65 ust. 4 Konstytucji, stanowiącym o minimalnej wysokości wynagrodzenia za pracę. Odnosząc się więc do art. 65 ust. 4 Konstytucji, powtórzenia wymaga twierdzenie utrwalone przez orzecznictwo, iż użyte we wskazanym przepisie pojęcie „praca” należy rozumieć $w$ sposób autonomiczny. Nie może być ono utożsamiane z pojęciami funkcjonującymi w szczegółowych gałęziach prawa. Przez wskazane pojęcie należy więc rozumieć wszelką pracę zarobkową na rzecz innego podmiotu, co tym samym obejmuje pracę zarobkową wykonywaną przez osoby pozbawione wolności bez względu na charakter stosunku prawnego, $\mathrm{w}$ ramach którego praca ta jest świadczona ${ }^{18}$. Analizując w przedmiotowym orzeczeniu niezgodność przepisu z konstytucyjną zasadą równości, wskazać należy, iż była ona upatrywana przez Trybunał w aspekcie nierównego traktowania podmiotów charakteryzujących się w równym stopniu tą samą istotną cechą, mianowicie faktem świadczenia pracy ${ }^{19}$. Mimo tego, iż pozycja osób skazanych świadczących pracę w warunkach izolacji znacząco różni się od pozycji pracowników pozostających w klasycznym stosunku pracy, to wskazana różnica nie może posiadać czynnika determinującego możliwość traktowania tych pierwszych w sposób odmienny, który jednocześnie stwarzałby wobec nich warunki obiektywnie gorsze. Czynnikami różnicującymi pozycje wyżej wskazanych grup jest fakt, iż osoby skazane pozostają w warunkach izolacji więziennej oraz świadczą pracę na podstawie innej niż stosunek pracy. Owe rozbieżności nie mogą stać się przyczyną odmiennego traktowania, zwłaszcza pod względem czynnika tak ważnego w punku widzenia świadczenia pracy, jakim jest wynagrodzenie. Zapewnienie każdej osobie świadczącej pracę w pełny wymiarze godzinowym, tego samego poziomu minimalnego wynagrodzenia, stanowi wyraz najsilniejszej ochrony pracy i musi być wywodzone nie z okoliczności, w jakich wykonywana jest praca, lecz z samego faktu jej wykonywania. Oznacza to, że świadczenie pracy w warunkach izolacji oraz warunkach wolnościowych, posiada taki sam walor, przez co musi być ono tak samo oceniane pod aspektem płacy. Według Europejskich Reguł Więziennych przyjętych w 2006 r. przez Komitet Ministrów Rady Europy, na które powołuje się Trybunał Konstytucyjny

\footnotetext{
${ }^{18}$ Tamże, s. 15.

${ }^{19}$ Tamże, s. 12.
} 
w uzasadnieniu omawianego wyroku $^{20}$, w każdym przypadku zapewnia się sprawiedliwe wynagrodzenie za pracę więźniów (reg. 26.10) ${ }^{21}$. Na gruncie postanowień Wzorcowych Reguł Minimalnych Postępowania z Więźniami przyjętych w 1955 r. przez I Kongres Narodów Zjednoczonych w sprawie zapobiegania przestępczości i postępowania ze sprawcami przestępstw, a które również zostały przywołane przez Trybunał Konstytucyjny w uzasadnieniu, więźniowie otrzymują za swoją pracę sprawiedliwe wynagrodzenie (reg. 76.1) $)^{22}$. Sprawiedliwe wynagrodzenie natomiast należy rozumieć, w zgodzie z postanowieniami Międzynarodowego Paktu Praw Gospodarczych, Społecznych i Kulturalnych, w których państwa strony zobowiązuje się do zapewnienia równego wynagrodzenia za pracę bez jakiegokolwiek rozróżnienia. Przywołane regulacje międzynarodowe ściśle korespondują z art. 32 Konstytucji Rzeczypospolitej Polskiej, który stanowi, że wszyscy ludzie są równi wobec prawa i nikt nie może być dyskryminowany $\mathrm{w}$ życiu politycznym, społecznym lub gospodarczym z jakiegokolwiek powodu, w więc również z faktu odbywania kary pozbawienia wolności ${ }^{23}$. Zasygnalizowania wymaga również fakt, iż przedmiotowy wyrok Trybunał Konstytucyjny dokonał stanowczego przemodelowania możliwości świadczenia pracy w warunkach odbywania kary pozbawienia wolności przez osoby skazane, ponieważ zmiana dolnej granic wysokości wynagrodzenia rażąco wpłynęła na wolę zatrudniania osób skazanych przez potencjalnych pracodawców ${ }^{24}$.

\section{Zasady dokonywania potrąceń i przekazywania wynagrodzenia osobom skazanym}

Kodeks karny wykonawczy w art. $242 \quad \S \quad 15$ wskazuje definicję wynagrodzenia przypadającego skazanemu, przez którą rozumie się kwotę pozostałą po dokonaniu potrąceń. Kwota wynagrodzenia pozostająca po dokonaniu wszelakich potrąceń, rozumiana jest jako kwota wynagrodzenia netto przypadająca za pracę skazanemu ${ }^{25}$. Regulacja obejmując katalog dokonywanych uszczupleń, uregulowana została na gruncie Kodeksu karnego wykonawczego

\footnotetext{
${ }^{20}$ Tamże, s. 8-9.

${ }^{21}$ Zalecenia rec (2006) 2 Komitetu Ministrów do państw członkowskich Rady Europy w sprawie Europejskich Reguł Więziennych (Przyjęte przez Komitet Ministrów w dniu 11.1.2006 r. na 952 posiedzeniu delegatów) https://edu.cossw.pl/file/redir.php?id=5853 (dostęp: 28.10 .2019 r.).

${ }^{22}$ Rezolucja 663C (XXIV) z dnia 31 lipca 1957 r. oraz 2076 (LXII) z 13 maja 1977 r., https://www.archbip.ms.gov.pl/pl/ministerstwo/wspolpraca-miedzynarodowa/wspolpraca-w-ramach--onz-i-obwe/standardyorganizacji-narodow-zjednoczonych-w-dziedzinie-wymiaru-sprawiedliwosci-w-sprawach-karnych/(dostęp: 28.10.2019 r.).

${ }^{23}$ G.B. Szczygieł, Penalties Execution Coderegulations with regard to employment of convicts from the perspestive of the EuropeanPrisonRules, „Ius Novum”2016, nr 2, s. 172.

${ }^{24}$ T. Kalisz, A. Kwieciński, Zmiany $w$ zakresie odpłatności za pracę skazanych a powszechność zatrudnienia $w$ polskim systemie penitencjarnym, (w:) Zmiany $w$ prawie karnym wykonawczym w latach 2009-2014, red. A. Kwiecień, Warszawa 2014, s. 17.

${ }^{25}$ I. Zgoliński, Objaśnienie wyrażeń ustawowych, w: Kodeks karny wykonawczy. Komentarz, red. J. Lachowski, Warszawa 2015, s. 829.
} 
w art. 125. Tenże przepis wskazuje, iż wynagrodzenie zostaje uszczuplone w dwojaki sposób. Po pierwsze, podlega ono zmniejszeniu w wysokości 7\% na cel Funduszu Pomocy Pokrzywdzonym oraz Pomocy Postpenitencjarnej, o którym mowa w art. 43 kodeksu. Po drugie, wynagrodzenie podlega umniejszeniu o 45\% na rzecz Funduszu Aktywizacji Zawodowej Skazanych oraz Rozwoju Przywięziennych Zakładów Pracy. Sumując powyższe, aż 52\% z wynagrodzenia za pracę skazanego zostaje potrącone na rzecz wymienionych funduszy, będących funduszami celowymi. Dokonywanie powyższych uszczupleń stanowi specyfikę wyłącznie pracy świadczonej przez osoby pozbawione wolności. Kodeks pracy mający zastosowanie do klasycznego zatrudnienia w warunkach wolnościowych, w art. 87 nie przewiduje możliwość dokonywania potrąceń na wcześniej wskazane fundusze celowe. Taki stan rzeczy mimowolnie różnicuje sytuację prawną skazanych w zakresie otrzymywania wynagrodzenia wyrażonego w wartości netto, znacząco tę wartość zmniejszając. Możliwość dokonywania potrąceń z wynagrodzenia osób skazanych, nieprzewidzianych dla innych pracowników, zarówno w ustawodawstwie krajowym, jak i międzynarodowym nie została wyraźnie zabroniona bądź dopuszczona. Jak wskazuje się jednak w doktrynie, konstrukcja wskazanych potrąceń odpowiada konstrukcji obciążeń podatkowych, które w tym wypadku nałożone są wyłącznie na grupę podmiotów świadczących pracę w warunkach izolacji więziennej. Oznacza to, iż czynnikiem warunkującym nałożenie obciążeń jest sam fakt pozbawienia wolność, bez względu na możliwość wykonywania identycznej pracy W warunkach wolnościowych, przez co wskazane potrącenia powinny być uznane za dyskryminujące ${ }^{26}$. Wynagrodzenie osób skazanych, tak samo jak i wynagrodzenie podmiotów pozostających w zwykłym zatrudnieniu pracowniczym, dodatkowo podlega umniejszeniu o wysokość składek na ubezpieczenie społeczne oraz o podatek dochodowy od osób fizycznych na zasadach ogólnych, jednakże z zastrzeżeniem podbierania składek na ubezpieczenia zdrowotne ${ }^{27}$.

Problematyka przekazywania wynagrodzenia skazanemu przez podmiot go zatrudniający uregulowana została w rozporządzeniu Ministra Sprawiedliwości z dnia 9 lutego 2004 r. w sprawie szczegółowych zasad zatrudniania skazanych ${ }^{28}$. Sposoby przekazywania płacy są ściśle determinowane poprzez istniejącą podstawę, na jakiej obywa

\footnotetext{
${ }^{26}$ J. Potulski, Zatrudnianie, (w:) Kodeks karny wykonawczy. Komentarz, red. J. Lachowski, Warszawa 2015 , S. 486.

${ }^{27}$ Art. 12a ustawy z dnia 27 sierpnia 2004 r. o świadczeniach opieki zdrowotnej finansowanych ze środków publicznych (tekst jedn. Dz.U. z 2019 r. poz. 1373).

28 Rozporządzenie Ministra Sprawiedliwości z dnia 9 lutego 2004 r. w sprawie szczegółowych zasad zatrudniania skazanych (Dz.U. z 2004 nr 27 poz. 242).
} 
się świadczenie pracy. W tym miejscu należy jedynie wspomnieć o treści art. $121 \S 2$ Kodeksu karnego wykonawczego, który wyróżnia następujące możliwe podstawy zatrudnienia osób skazanych: skierowanie do pracy, umowa o pracę, umowa zlecenie, umowa o dzieło, umowa o pracę nakładczą. Przedstawione wyliczenie nie ma przymiotu wyliczenia taksatywnego, co wyraźnie zostało zaznaczone in fine przywołanego przepisu, poprzez wskazanie możliwości zatrudnienia w ramach innej formy prawnej niż wyżej wymienione.

W przypadku skierowania do pracy podmiot zatrudniający przekazuje wynagrodzenie wraz z listą płac do zakładu karnego, w którym przebywa skazany w terminie określonym w umowie dotyczącej skierowania do pracy, nie później jednak niż do 10 dnia każdego miesiąca za miesiąc poprzedni (§7 ust. 3 rozporządzenia). Jeżeli praca wykonywana jest na podstawie umowy zlecenia, umowy o dzieło lub umowy o pracę nakładczą, zatrudniający na takich samych zasadach co opisane powyżej dostarcza wynagrodzenie wraz z listą płac w terminie określonym w porozumieniu zawartym między dyrektorem zakładu karnego, w którym przebywa skazany a podmiotem go zatrudniającym ( 77 ust. 2 w zW. z $\S 6$ ust. 3 rozporządzenia). Natomiast w przypadkach, gdy praca świadczona jest na podstawie umowy o pracę, podmiot zatrudniający zobowiązany jest do dostarczenia listy płac wraz z wynagrodzeniem do 10 dnia każdego miesiąca za miesiąc poprzedni. W ostatnim przypadku termin przekazania wynagrodzenia został ustalony W analogiczny sposób, w jaki uczynił to ustawodawca na gruncie art. 68 Kodeksu pracy, a więc na podobnych zasadach, jakie mają zastosowanie do klasycznego zatrudnienia pracowniczego.

\section{Przestój w świadczeniu pracy}

Ogólną zasadę, jaką można wywieść z przepisów Kodeksu karnego wykonawczego, odnoszącą się do wynagrodzenia za pracę, ustawodawca sformułował w ten sposób, iż wynagrodzenie osobie skazanej przysługuje wyłącznie za pracę wykonaną. Tak zarysowana zasada odpowiada dokładnie temu, co zostało zawarte w art. 80 Kodeksu pracy, a więc regulacji mającej zastosowanie do zatrudnienia pracowniczego. Od wskazanej zasady, zarówno na gruncie Kodeksu pracy, jak i Kodeksu karnego wykonawczego istnieją wyjątki, które wprowadzone zostały przepisami prawa i tylko w takim zakresie, w jakim zostały określone w przepisach, mogą być stosowane.

Analizując regulację dotyczącą wykonywania pracy przez osoby skazane, zaznaczyć należy, że w myśl art. $123 \S 4$ wyjątkiem od braku wypłaty wynagrodzenia za pracę 
niewykonywaną jest sytuacja, w której skazany, będąc gotów do świadczenia pracy, doznał przeszkód w jej wykonywaniu, z przyczyn dotyczących podmiotu zatrudniającego. Taka sytuacja, jaką wskazuje przepis, może zaistnieć wyłącznie po spełnieniu się kumulatywnie dwóch przesłanek. Po pierwsze, gotowość świadczenia pracy przez osobę skazaną. Po drugie, przeszkoda, jaka zaistniała, nie wynika z winy skazanego, lecz leży po stronie podmiotu zatrudniającego. Jak podkreśla orzecznictwo, gotowość do pracy oznacza pozostawanie osoby mającej świadczyć pracę do dyspozycji pracodawcy w zakładzie pracy lub w innym umówionym miejscu ${ }^{29}$ przy możliwości niezwłocznego jej podjęcia na wezwanie pracodawcy $^{30}$. Przeszkoda powstała po stronie podmiotu zatrudniającego silnie związana jest z ryzykiem technicznym i odnosi się do niemożliwości świadczenia pracy wskutek wystąpienia w zakładzie pracy awarii maszyn i urządzeń czy innych technicznych przeszkód w wykonywaniu pracy, nie wyłączając siły wyższej ${ }^{31}$. W tym miejscu na szczególną uwagę zasługuje art. $123 \S 6$ Kodeksu karnego wykonawczego, który czyni istotne wyłączenie W zakresie przyczyn przestoju leżących po stronie podmiotu zatrudniającego. W myśl wskazanego przepisu, osobie skazanej przysługuje wynagrodzenie za czas przestoju spowodowanego warunkami atmosferycznymi - a więc warunkami siły wyższej - jedynie wtedy, gdy tak stanowi porozumienie lub umowa, na podstawie której świadczona jest praca. $\mathrm{W}$ razie więc braku takiego uregulowania w umowie lub porozumieniu, mimo gotowości skazanego do wykonywania pracy, wynagrodzenie będzie mu nienależne. Poczynione przez ustawodawcę zastrzeżenie dotyczące warunków atmosferycznych stanowi wyłączną specyfikę wykonywania pracy przez osoby skazane, co oznacza, iż nie ma ona zastosowania do klasycznego zatrudnienia na podstawie stosunku pracy. Taki stan rzeczy pozwala na ograniczenia ryzyka podmiotu zatrudniającego osoby skazane, pozwalając mu zabezpieczyć się przed wypłacaniem wynagrodzenia za faktycznie niewykonywaną pracę. Omawiane ograniczenie $\mathrm{z}$ jednej strony stanowi zachętę dla pracodawców do zatrudniania osób pozbawionych wolności, jednakże z drugiej strony stanowi kolejny wyraz różnicowania sytuacji osób skazanych, wyłącznie dlatego, iż świadczą oni pracę w warunkach izolacji więziennej. Oceniające zasadność omawianego wyjątku, uznać należy, iż tworzenie ustawowych ułatwień dla pracodawców nie może odbywać się - jak ma to zastosowanie w tym przypadku - w sposób uwypuklający nierówne traktowanie skazanych.

\footnotetext{
${ }^{29}$ Wyrok Sądu Najwyższego z dnia 26 czerwca 1998 r.,I PKN 195/98, OSNAPiUS 1999, nr 14, poz. 453.

${ }^{30}$ Wyrok Sądu Najwyższego z dnia 2 września 2003, I PK 345/02, OSNAPiUS 2004, nr 18, poz. 308.

${ }^{31}$ J. Piątkowski, Aksjologiczne i normatywne podstawy prawa stosunku pracy, Toruń 2017, s. 121.
} 


\section{Podsumowanie}

Praca osób pozbawionych wolności, jak już wspominano kilkukrotnie, ma ogromny wpływ na postawy skazanych. Kwestią odrębną, pozostającą poza obszarem rozważań podjętych w ramach niniejszego opracowania, jest odpowiedni dobór pracy dla osoby skazanej, tak by była ona dla niej twórcza, mogąca zdobyć cała jej osobowość, aby móc w konsekwencji stać się właściwym narzędziem uspołecznienia ${ }^{32}$. Oceniając regulacje prawne określające warunki i zasady przyznawania wynagrodzenia osobom skazanym za świadczoną przez nich pracę, wskazać należy, iż ich kształt różni się od zasad zatrudniania osób pozostających w klasycznym stosunku pracy. Różnice te jawią się między innymi w wysokości wynagrodzenia, zarówno - jak było to w poprzednio obowiązującym stanie prawnym - co do minimalnej wysokości płacy oraz - jak jest to obecnie - co do dokonywanych potrąceń na rzecz funduszy celowych. Odmienności upatruje się również w opisywanym wcześniej sposobie przekazywania wynagrodzenia, gdzie rolę pośredniczącą między podmiotem zatrudniającym a skazanym pełni administracja zakładu karnego. Na uwagę zasługuje również przywoływany art. $123 \S 6$ Kodeksu karnego wykonawczego, wprowadzający charakterystyczny wyłącznie dla zatrudnienia osób skazanych wyjątek, co do wypłaty wynagrodzenia za czas przestoju spowodowany warunkami atmosferycznymi. Akty prawa międzynarodowego wytyczające poziom standardów traktowania więźniów stanowią jedynie, iż państwa zobowiązane są do zapewnienia pracy osobom skazanym na wzór warunków wolnościowych. Tak sformułowana dyrektywa w żaden sposób nie neguje możliwości istnienia przepisów, które ustanawiałyby odmienną pozycję prawną osób wykonujących pracę w warunkach izolacji. Jednakże pamiętać należy, iż podstawą takiej dyferencjacji nie może fakt wykonywania kary pozbawienia wolności przez osobę świadczącą pracę, gdyż takie działanie stałoby w sprzeczności z konstytucyjną zasadą równości.

\section{Bibliografia:}

\section{Literatura}

Dawidziuk E., Traktowanie osób pozbawionych wolności we wspótczesnej Polsce na tle standardów międzynarodowych, Warszawa 2013

\footnotetext{
32 J. Śliwkowski, Prawo i polityka penitencjarna, Torun 1978, s. 132.
} 
Kosut A., Zatrudnienie skazanych w świetle projektu zmian kodeksu karnego wykonawczego z 2001 r., „Przegląd Więziennictwa Polskiego” 2001, nr 32-33

Kalisz T., Kwieciński A., Zmiany $w$ zakresie odpłatności za pracę skazanych a powszechność zatrudnienia $w$ polskim systemie penitencjarnym, Zmiany w prawie karnym wykonawczym w latach 2009-2014, red. A. Kwiecień, Warszawa 2014

Kuć M., Prawne podstawy resocjalizacji, Warszawa 2011 Liszcz T., Zatrudnienie skazanych odbywajacych kare pozbawienia wolności (podstawowe zagadnienia prawne), „Państwo i Prawo” 1989, z. 2

Piątkowski J., Aksjologiczne $i$ normatywne podstawy prawa stosunku pracy, Toruń 2017 Potulski J., Zatrudnianie, Kodeks karny wykonawczy. Komentarz, red. J. Lachowski, Warszawa 201

Śliwkowski J., Prawo i polityka penitencjarna, Toruń 1978

Szczygieł G.B., Penalties Execution Coderegulations with regard to employment of convicts from the perspestive of the EuropeanPrisonRules, „Ius Novum”, 2016, nr 2

Zgoliński I., Objaśnienie wyrażeń ustawowych, w: Kodeks karny wykonawczy. Komentarz, red. J. Lachowski, Warszawa 2015

\section{Orzecznictwo}

Wyrok Trybunału Konstytucyjnego z dnia 13 grudnia 2004 r., K 20/04, Dz.U. Nr. 273, poz. 2720 Wyrok Trybunału Konstytucyjnego z dnia 7 stycznia1997 r., K 7/96 OTK 1997, Nr 1, poz. 1 Wyrok Trybunały Konstytucyjnego z dnia 23 lutego 2010 r., P 20/09 Dz.U. Nr. 34, poz. 191 Wyrok Sądu Najwyższego z dnia 26 czerwca 1998 r. I PKN 195/98, OSNAPiUS 1999 nr 14, poz. 453 Wyrok Sądu Najwyższego z dnia 2 września 2003, I PK 345/02, OSNAPiUS 2004 nr 18, poz. 308 